\title{
Closing the Gap in Undergraduate Supply Chain Education through Live Experiential Learning
}

\author{
Sime Curkovic, Nathan Fernandez \\ Center for Integrated Supply Management, Haworth College of Business, Western Michigan University, \\ Kalamazoo, MI, USA \\ Email: sime.curkovic@wmich.edu,nathan.e.fernandez@wmich.edu
}

Received 6 May 2016; accepted 31 May 2016; published 3 June 2016

Copyright (C) 2016 by authors and Scientific Research Publishing Inc. This work is licensed under the Creative Commons Attribution International License (CC BY). http://creativecommons.org/licenses/by/4.0/

c) (i) Open Access

\begin{abstract}
With the supply chain industry suffering from a lack of available managerial talent, U.S. companies are stepping up efforts to recruit qualified and skilled professionals from universities. The supply chain industry will need to fill about 1.4 million new jobs over the next four years, but there are concerns regarding where the talent will come from given that demand greatly exceeds supply. The U.S. Bureau of Labor Statistics predicts that employment for supply chain management will increase by 20 percent through 2018, which is nearly twice as fast as the 11 percent average for all industries combined. The Georgia Center of Innovation also reports that the U.S. will be short one million supply chain workers in $\mathbf{2 0 1 6}$ alone. Related to the talent shortage, industry has also made clear that they are struggling to evolve their supply chain processes to match business needs. Nearly a third of all supply chain processes are inadequate, according to research from Crimson \& Co. In response to these industry demands, Western Michigan University's Integrated Supply Management Program has placed a strong focus on process management through lean problemsolving techniques. This paper reflects on the industry factors that are currently hampering the process of matching new college graduates with professional positions. It also describes how WMU's ISM undergraduate program is successfully bridging those gaps and preparing its students by partnering with local businesses on live experiential learning projects.
\end{abstract}

\section{Keywords}

Supply Chain Management, Value Stream Mapping, Experiential Learning, Problem-Solving

How to cite this paper: Curkovic, S. and Fernandez, N. (2016) Closing the Gap in Undergraduate Supply Chain Education through Live Experiential Learning. American Journal of Industrial and Business Management, 6, 697-708.

http://dx.doi.org/10.4236/ajibm.2016.66064 


\section{Introduction}

According to the U.S. Department of Education, there are currently over 21 million college students. With the supply chain industry suffering from a lack of available talent for management positions, U.S. companies are stepping up efforts to recruit qualified and skilled professionals from universities. The supply chain industry will need to fill about 1.4 million new jobs over the next four years, but there are concerns regarding where the talent will come from given that demand greatly exceeds supply [1] [2]. The Georgia Center of Innovation also reports that the U.S. will be short one million supply chain workers in 2016 alone [3]. The talent shortage is one of the major barriers impeding innovation in the supply chain. The number of available positions is likely to inflate in coming years as the Baby Boomer generation reaches retirement age and the need for workers with experience in engineering, analytics, contract management, negotiation, and advanced manufacturing continues to rise [4] [5].

All these findings are also reflected in another report by the Haslam College of Business at the University of Tennessee [2] [6]. While the shortage is well known, the report maintains the talent gap encompasses every level of supply chain management and is likely to grow worse as Baby Boomers retire. The U.S. Bureau of Labor Statistics predicts that employment for supply chain management should increase by 20 percent through 2018, which is nearly twice as fast as the 11 percent average for all industries combined [2]. Deloitte's third annual Supply Chain Survey, released last year in 2015, stated: “...many organizations are confronting critical shortfalls of talent. Years of headcount reduction, training-budget cuts, and the retirement of highly skilled individuals have hollowed out the ranks of veteran professionals” [7]. The U.S. Roadmap for Material Handling \& Logistics predicts that there will be 1.4 million new jobs in the logistics and supply chain field by 2018. By 2017, it is expected that the number of supply chain employees will increase from a rate of 8.4 percent for tactical occupations, to 14.9 percent for managerial occupations [8]. The demand for critical talent in the supply chain will continue to grow.

Industry has also made clear that businesses are struggling to evolve their supply chain processes to match business needs. Nearly a third of all supply chain processes are inadequate, according to research from Crimson \& Co. Every company needs to configure its processes to support priorities, allowing the supply chain to deliver against business objectives [9]. The supply chain is increasingly recognized as a key enabler of competitive advantage but understanding its requirements is a major industry challenge. The Western Michigan University's (WMU) Integrated Supply Management (ISM) program has addressed this issue and is also heralding a national accolade that puts it among the top supply chain programs with a strong focus on process management and lean problem-solving.

In 2014, the WMU ISM program was ranked No. 5 on Gartner's Top U.S. Supply Chain Undergraduate University Programs. In addition to the overall No. 5 ranking, Gartner lists WMU as the top leader in its program scope category. This was in recognition of the unique combination of supply chain management, engineering, information technology and business education that prepares undergraduates for challenging and high-paying careers. Software Advice, a company that does detailed research on thousands of supply chain software applications as well as system analysis, also named the WMU ISM program second in the nation for its emphasis on teaching technology, software, and quantitative tools in its undergraduate program. Our paper reflects on the factors that are currently hampering the process of matching new college graduates with professional positions; and how WMU's ISM program is successfully bridging those gaps and preparing its students by partnering with local businesses.

\section{The Student}

A student's success in graduating from college sets the stage for the rest of their professional career. College is a means to the overall success of professional and personal goals. The success of these goals attained by students ultimately increases their overall well being.

According to the American Management Association, businesses consider new college graduates to be three times more likely to be below average and of the lowest ability, as opposed to evaluating experienced workers under the same conditions. In this instance, graduates underestimate the job requirements, and employers overestimate the graduate's credentials/abilities [10]. To deal with this expectation gap, companies are taking precautions to protect themselves. Instead of hiring new graduates with no real world business experience, corporations are instead investing in students that have proven themselves within internship experiences that develop 
leadership and problem-solving skills. These valuable skills that students acquire through professional experiences are highly sought after in today's job marker. In fact, the vast majority of employers now think that students should have at least one or two internships before graduation [11] [12].

Peter D. Hart Research Associates, Inc. evaluated some of the key similarities and differences in expectations between college graduates and employers [13]. Hart interviewed more than 500 graduates and over 300 businesses. In Figure 1, recent graduates and employers picked their two most critical skills. The rankings are very similar in a majority of the categories. Teamwork skills rank number one for both parties, followed by critical thinking/problem-solving and oral/written communication.

The similarities in the data show where universities have already made advancements to their teaching methods. Students can easily recognize the worth of these skills because they observe the emphasis that the job market and colleges have placed on them. Colleges that concentrate on these areas are able to give students a competitive advantage over graduates from other programs. An even more telling study begins in the areas that potential employers say colleges need to improve.

\section{The Business}

Subsequently, employers were asked, "what areas should colleges focus more attention?” Below are their top three responses [13]:

1. Concepts and new developments in science and technology—-82\% agreed.

2. Teamwork skills and the ability to collaborate with others in diverse group settings $-76 \%$ agreed.

3. The ability to apply knowledge and skills to real-world settings through internships or other hands-on experiences-73\% agreed.

The most common answer suggests that employers want students to be more conscious of the business environment into which they are entering. In the second reply, employers state that even though students understand its high priority, the teamwork abilities of college graduates are often not enough to meet their team-oriented standards. In the third highest response, most companies felt that colleges need to concentrate on developing students to deal with real world problems and their solutions. With very similar results, a NACE 2013 Job Outlook report identified leadership as the attribute that employers seek most on a resume, followed in rank order by problem-solving skills, written communication, teamwork, analytical skills, work ethic, verbal communication, initiative, computer skills, technical skills, detail-oriented, adaptability, interpersonal skills, organizational ability, friendly, strategic planning skills, creativity, entrepreneurial, and tactfulness.

One method that universities can utilize to instill students with all of these skills and values is by organizing classrooms into functional teams and challenging them with complex business circumstances to improve, and

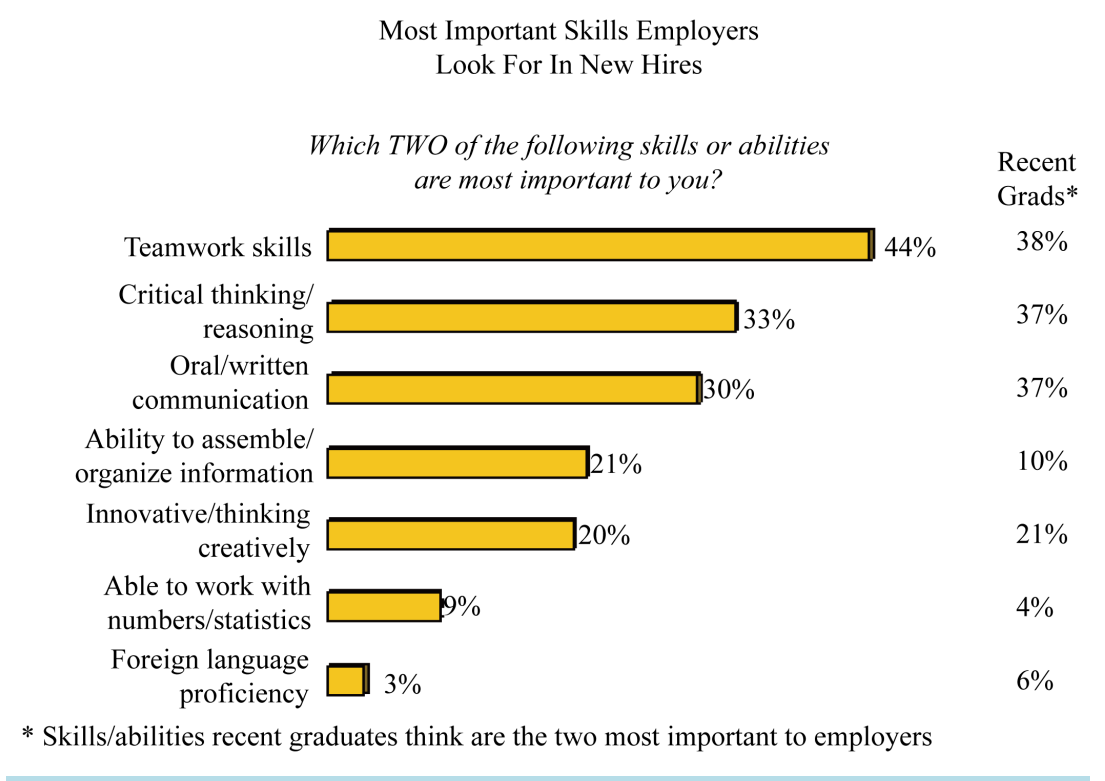

Figure 1. Peter hart research associates: most important skills ranked by employers. 
then having the teams report their solutions to industry managers [14]-[20]. Schools create these settings through case studies, simulations, and working with local organizations to real world problems [21]-[26]. This theory has been discussed at great lengths in the literature as noted with numerous previous references, and Western Michigan University has taken these theories into practice.

\section{Western Michigan University's Integrated Supply Management Program}

The responses by employers in Hart's and the NACE research symbolize clear-cut areas where employers feel that most college graduates are inadequate (i.e., leadership, problem-solving, teamwork, etc.). However, for students in southwest Michigan, WMU is practicing several successful strategies to close the gap between student abilities and employer expectations. WMU's ISM undergraduate program boasts a rigorous curriculum, which combines traditional approaches to teaching and also takes students beyond the classroom to better prepare them for real-world problem solving.

WMU's ISM program requires engagement in many challenging courses such as engineering graphics and processes/materials in manufacturing. These classes place a heavy emphasis on understanding and practicing engineering principles; skills that are often critical to the success of supply chain graduates. Very frequently, members of the supply chain are required to collaborate with engineers and quality personnel on new product launches or to maintain positive production quality. These two classes are among five engineering courses that stretch the product and process knowledge of WMU students. As a result, WMU's ISM graduates are leaving school with an engineering background. Because its program is heavily weighted towards manufacturing, students have a fundamental knowledge of metal, plastic, and rapid prototyping manufacturing; which has translated well in careers for global companies such as Ford Motor Company, General Motors, Honda, John Deere, Whirlpool, and Stryker (Table 1).

In addition to its engineering coverage, WMU's ISM program also requires several business requirements. WMU has designed the program in such a way that students are not pigeon-holed into a few career paths. WMU graduates have proven to be prepared to assume a wide variety of roles within purchasing, operations, project management, logistics, and across several other disciplines. Often, people are unaware of the breadth and depth of the employment opportunities within supply chain management. From marketing to data analysis and human resources, supply chain firms are seeking managers across departments.

WMU's courses also offer an in depth study of systems such as ERP (using SAP) and CAD, while improving students' abilities with programs in Microsoft Office applications (i.e., using MS Excel for data analytics and MS Access for database management and mining). Power BI and Tableau have likewise been built into the curriculum IT courses. Being well-versed in many areas as well as possessing essential knowledge of today's latest software and systems provides WMU ISM graduates with a competitive advantage in the marketplace over students that typically take half as many credit hours in their supply chain curriculums with next to no emphasis on technical and data analytic skills (Table 2).

The WMU ISM curriculum consists of twice the amount of required credits as other highly ranked programs. Out of 43 required supply chain major credits, WMU's ISM program offers 16 engineering focused credits (4 classes), 12 management credits (4 classes), 6 marketing credits (2 classes), 3 law credits (1 class), and 6 supply chain related credit electives (2 classes). The ISM required classes include: EDMM 1420-Engineering Graphics, EDMM 3280-Quality Assurance and Control, EDMM 1500 \& 1501-Processes and Materials in Manufacturing, MGMT 2800-Introduction to Supply Management, MGMT 3200-ERP System Management, MGMT 3810-Experiential Live Lean Problem-Solving Projects, MGMT 4640-Production Management and Control, MKTG 3720-Purchasing Management, MKTG 4630-Manufacturing Logistics, LAW 4840-International Business

Table 1. Average Starting Salary for WMU’s ISM graduates 2012-2013: \$62,896.

Job Titles

Traditional Employers That Recruit WMU's ISM Graduates
Buyer, Materials Planner, Supply Chain/Logistics Analyst, Contracts Representative, Purchasing Manager, Production Scheduler, Production Manager, Project Manager, Inventory Manager, Logistics Coordinator, Operations Supervisor, Supply Chain/SAP Coordinator, Scheduling Coordinator.

American Axle, Bendix, Coca-Cola, Coyote Logistics, Eaton, Exel Supply Chain, Expeditors International, Ford Motor Company, GE Aviation, General Motors, Honda, IBM, John Deere, Kohler, Kellogg's,

Marathon Oil, Perrigo, Stryker Instruments, Stryker Medical, Texas Instruments, Meijer, Monsanto, Total Quality Logistics, US Defense Logistics Agency, and Whirlpool. 
Table 2. Credit requirements.

\begin{tabular}{cc}
\hline University & Required Credits \\
\hline Western Michigan University & 43 \\
Arizona State University & 21 \\
Michigan State University & 18 \\
Penn State University & 24 \\
University of Texas, Austin & 21 \\
\hline
\end{tabular}

Law w/Advanced Contract Negotiation, EDMM 4870-Manufacturing Productivity Techniques or GEOG 3010Fundamentals of Geographic Information Systems or IME 5120-Management of Service Operations, and EDMM 4880/MKTG 4880-Applied Process Reengineering.

The elective courses give students the opportunity to pursue areas such as finance and accounting and data analytics, or students have the option to earn a minor/second major in place of ISM-related electives. Over half of the students have decided to take the new business analytics minor, which develops data analytic, database management, and data mining skills. Employers have sent the message to students that they will pay a premium for these IT skills that heavily compliment the supply chain field. The variety of the program and its flexibility to student needs increases the likelihood of graduates receiving attractive jobs after school. It has also lead to an increase in starting salary for WMU ISM graduates.

Nationally, Fall 2012 and Spring 2013 supply chain graduates reported an average starting salary of \$48,431 USD [13], while WMU ISM graduates reported an average starting salary of around $\$ 58,000$ for the same time frame, with around $20 \%$ of the students getting offers for over $\$ 60,000$. This wage gap of over $\$ 10,000$ reflects how WMU is shifting the demand curve for its graduates and therefore increasing benefits that they receive with their new employers. Within the first three months of leaving school, close to $100 \%$ of WMU's ISM graduates find a full-time managerial position.

\section{Management 3810-Live Experiential Lean Problem-Solving Projects}

The mission of WMU's ISM program is to influence the evolution of supply management theory and practice through scholarly teaching, discovery, integration and application. Management 3810 is a non-traditional class that capitalizes on the program's overall key missions and is typically taken by students that are approximately half way through their supply chain major coursework. Problem-solving learning pedagogy is very well-suited to connecting learning within and across courses in a way that aligns with accreditation standards and learning outcomes. Problem-solving learning offers a collaborative, dynamic pedagogy for bringing together industry professionals, faculty, and students to tie theory into practice. This class builds on prior appeals for projectbased learning [14]-[26], and was specifically inspired by the work done by Sroufe and Ramos [25] [26].

WMU faculty work with local business leaders/clients to identify problem-solving opportunities for its students to improve throughout a semester-long project. Within the confines of the course structure, students manage the task under direct supervision of a faculty member and from project leaders at the sponsoring company. These clients that work with WMU students on these ventures have a supply chain issue or constraint, and use students as a resource to provide solutions. The problems that are posed to students, as well as the business impact of these projects, are hands-on and real. As a result, companies that choose to work with WMU on projects must know that they will receive good value; and in return the students receive invaluable professional work experience in solving real-world supply chain problems.

Only upperclassmen are able to enroll for the course, which ensures that students have a fundamental knowledge of supply chain management concepts and techniques. Building on this basic foundational understanding, professors provide lean training on critical concepts before the students have a kick-off meeting with the local businesses. Among these concepts are the A3 structured approach to problem solving, the Single-Minute Exchange of Die (SMED) system, value stream mapping techniques, Lean Six Sigma, and 5S to name a few. After mastering these process management concepts and techniques, students are then given the chance to gain experience by applying these tools to an on-site industry process. 
The course provides student teams with a project formulated by professors and industry partners, such as Stryker, Whirlpool, Kellogg, Eaton, Steelcase, Texas Instruments, Mann-Hummel, Eliason, Parker Hannifin, Bronson Hospital, and Mercedes Benz Technology, allowing the teams the opportunity to create solutions and then apply them to improve a company's operations. The collaboration with industry partners provides every student with the unique opportunity to apply their in-class learning to the goals of successful corporations, giving the students a professional work experience.

The primary objective of this course is to extend the student's knowledge of the basic elements, issues, and problems facing the firm's supply chain. This course builds on the concepts introduced in previous courses and offers more detail regarding supply chain strategies, operating practices, and principles. The course is designed to provide students with an understanding of the design, implementation, and broad management of the effective and efficient integrated supply chain systems, by solving real world industry issues specifically using the A3 problem solving process. The class has sponsored over 100 industry projects since 2008 and has saved its industry partners millions of dollars while also helping improve their performance along the competitive dimensions of quality, service, and flexibility.

\subsection{Course Description}

Taught as a seminar for shared learning, best practices, and knowledge across teams and clients, the course requires all students to examine issues beyond their project scope and client concerns. Students work in teams to frame problems, develop solution paths, and manage projects from conception to completion for a company. The focus is on improving processes, driving innovation, and creating a competitive advantage-both short and long term—for organizations. Client deliverables include a formal presentation to the client management team that will lead to productivity gains, cost savings, revenue increases, and profit growth when implemented by the client. Note, some student project teams are able to implement their recommendations if time permits under the confines of a four-month semester. However, all student groups are required to make implementation recommendations at a bare minimum. Also, several client companies have the projects evolve from one semester to the next over a period of time in order to add more value to the client, so the projects build off of one another. The core mission is to provide meaningful opportunities for students to authenticate best practices in supply chain management while developing professional skills for managing people, processes and resources.

\subsection{Alignment with Undergraduate Program Goals}

Building on other foundational courses in the business college, students apply concepts and models from marketing, finance, accounting, operations, law, human resources, economics, statistics, information technology, and their signature supply chain courses. Students develop and test hypotheses; conduct primary and secondary research; collect and analyze data; establish goals and metrics and action plans; and prepare persuasive proposals and presentations in order to align course goals with the learning objectives of the business college.

\subsection{Course Pedagogy}

Serving as consultants with external clients, students represent WMU and the ISM program. Their clients are looking for new ideas for improving competiveness and profitability. They expect rigorous analysis, both quantitative and qualitative, that reflects the breadth and depth of an accredited, globally-recognized curriculum. The clients do prepare a preliminary project description, but the student team must refine and articulate project goals, scope, tasks, timetables and deliverables.

Faculty function as senior partners and risk managers for the student team consulting engagements, providing overall direction, including standardized templates, tools, and protocols to assure quality control. Faculty preview all documents and presentations before they share them with their clients to ensure sound reasoning and professionalism. This screening step limits risk for the student and the university while the students are learning. The course schedule lists formal checkpoints and status reviews, but faculty are also available for informal coaching, and students have access to the expertise of professionals throughout their educational community. For example, a warehousing project might require the direction of a faculty member in the college of engineering who has that specific area of expertise. 


\section{Phases of the Process Improvement Project}

Each group will submit a description of at least 1 process (1/2 to 1 page each) that they would like to evaluate. Typically, the faculty member will identify several options from local companies and the students then choose based on interest. The process cannot be a process that is already undergoing an improvement effort. The students must have access to an actual process and be able to gather data from it.

In order to move forward with a student project, the team must complete a proposal sheet to ensure that they understand the criteria for their projects. To begin attempting to solve a problem, that team will need to meet certain requirements including; a project title, a "Company/Client Project Champion" from the hosting company, a clearly defined project scope, project deliverables (specific and measurable), and background information on the company. This is an essential requirement due to the fact that as faculty, we need to be able to have certain deliverables to make sure the companies will be satisfied.

From these process descriptions, the group will select with the instructor's input a process to analyze. Examples of good processes for analysis from previous classes include (other examples can also be found in Table 5):

- The medical record completion process at a major hospital.

- A warranty claim process.

- The Receiving process at a major hospital.

- The process of assembling, preparing, and packing components for shipment.

\subsection{Group Presentation}

The groups will make a preliminary presentation early in the semester. Each group will have 15 minutes for this presentation. This presentation will be a description of the current process (which will include a process map), an evaluation of performance measures for the process (both current performance measures and suggested additions/changes), and a short discussion of where the problems are and where/how they expect to make improvements.

A final presentation of the project will be made to the class that will consist of a brief review of the process; the analyses performed on the current process; recommended process changes; impact of those process changes and a project plan for implementation. Each group will have 25 minutes for this presentation and they must use the A3 problem solving format. These presentations are typically done on-site at the client's facility since it typically involves several managers and proprietary information. Most of the companies require students to sign a non-disclosure agreement before the projects begin as well.

The presentations will be graded on the following criteria:

- Quality of PowerPoint or Prezi Slides (per client's preference).

- Correct Level of Detail per the A3 problem-solving format (Table 3).

- Participation of all group members (of which all will evaluate each other).

- Speaking quality (eye contact, spoken not read, projection).

- Time management.

\subsection{Written Project}

The group will then be required to submit a written project. The criteria for the written project are as follows:

- Executive summary.

- Table of contents.

- Brief description of the organization.

- Description and map of the existing process.

- Analysis of the existing process.

- Analysis of performance measures.

- Recommended changes to the process and new process map.

- Expected benefits of the changes to the process (in terms of recommended performance measures).

- Project plan for implementation (including time and resources).

- Tables and Figures, labeled and referenced.

\subsection{Project Management Process}

The following approach summarizes Chapters 1 through 5 of the course text, The McKinsey Mind [25] [26]. 
Table 3. A3 analysis requirements.

\begin{tabular}{|c|c|}
\hline Step & Description \\
\hline Theme & What are we trying to do? \\
\hline Background & $\begin{array}{l}\text { - } \quad \text { Background of the problem } \\
\text { - } \quad \text { Impontext required for full understanding } \\
\text { - Impe of the problem }\end{array}$ \\
\hline Current Condition & $\begin{array}{l}\text { - } \quad \text { Diagram of current situation (or process). } \\
\text { - } \quad \text { Highlight problem(s) with storm bursts } \\
\text { - } \quad \text { Extent of the problem(s), i.e., measures }\end{array}$ \\
\hline Cause Analysis & $\begin{array}{ll}\text { - } & \text { List problem(s) } \\
\text { - } & \text { Most likely direct (or root) cause } \\
\text { - } & \text { Five why }\end{array}$ \\
\hline Target Condition & $\begin{array}{l}\text { - } \quad \text { Diagram of proposed new process } \\
\text { - } \quad \text { Countermeasures noted as fluffy clouds } \\
\text { - Measurable targets (quantity, time) }\end{array}$ \\
\hline Implementation Plan & $\begin{array}{l}\text { - What actions need to be taken? } \\
\text { - Who is the responsible person? } \\
\text { - When does this take place? } \\
\text { Where does this take place? }\end{array}$ \\
\hline Follow up & $\begin{array}{l}\text { - Plan how you will check the efforts } \\
\text { - When will you check them? }\end{array}$ \\
\hline
\end{tabular}

Chapters 6 and 7 offer additional insight to managing the team, your client and yourselves. Table 4 shows the steps that are required to manage projects effectively. Students are expected to be well-versed in the contents of Table 4.

\section{A3 Problem Solving}

The format follows a very specific line of thinking and the desired outcome is that students will begin to use it to assess any problem they face in industry settings. The first step that students must complete is to decide the theme of the project. This helps the group decide what they are attempting to accomplish (Table 3). All of this information will need to fit on an A3 size sheet of paper or an $11 \times 17$ inch piece of paper. Toyota created this problem-solving technique. The A3 approach is now used by the majority of companies in the auto industry and several other industries throughout the global economy. Most of the companies that participate in this course already use the A3 process for their internal continuous improvement courses. The idea is that everyone has to be able to solve problems, but you have to keep it simple. Otherwise, changes are never made. Students must be able to state on their resume that they have problem solving skills. An example of the A3 format is listed below (Figure 2).

The A3 problem-solving format is a structured approach to problem solving based on fundamentals inspired by Toyota Motor Corporation. Toyota is known for its ability to manufacture high quality products through continuous process improvements. Their engineers, supervisors, and management all use the A3 problem-solving tool. This concise document provides a standard for implementing positive change [27]. The user follows a ten-step process improvement roadmap and also clearly defines the problem on a one page A3 problem-solving format.

This technique is extremely helpful for students to easily identify root causes for solving complex manufacturing problems. Several companies in southwest Michigan have repeatedly offered their manufacturing issues for projects with WMU because they have seen significant and positive results in the past. Two businesses that have worked on multiple occasions with WMU students are Companies A and B, which are described in the next section.

\subsection{Company A}

Company A is a publicly traded Fortune 500 manufacturing company headquartered locally to WMU and has 
Table 4. Managing projects effectively.

\begin{tabular}{|c|c|}
\hline Steps: & Milestones: \\
\hline $\begin{array}{l}\text { 1. Frame the Problem } \\
\text { a. Analyze the client's situation and needs } \\
\text { b. Identify the key issues } \\
\text { c. Determine problem(s) to solve why }\end{array}$ & 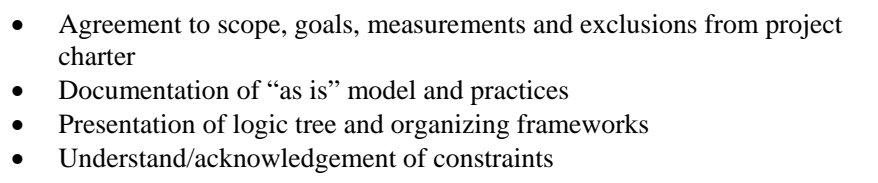 \\
\hline $\begin{array}{l}\text { 2. Develop/Screen Hypothesis } \\
\text { a. Articulate idealized state by brainstorming the } \\
\text { possibilities ("What could be") } \\
\text { b. Define any project boundaries }\end{array}$ & $\begin{array}{l}\text { - Working agreement on which possibilities align with mission and values } \\
\text { - "QDT” analysis (See Chapter 1) } \\
\text { - Refined scope document }\end{array}$ \\
\hline $\begin{array}{l}\text { 3. Design the Analysis } \\
\text { a. Determine information needed to prove/disprove } \\
\text { hypotheses } \\
\text { b. Structure analysis; select appropriate tools }\end{array}$ & $\begin{array}{l}\text { - Work plan—tasks, duties, timetable_-aligned to "big picture" and client } \\
\text { culture } \\
\text { - Identification of key drivers/factors that have major impact on problem(s) }\end{array}$ \\
\hline $\begin{array}{l}\text { 4. Gather "Smart" Data } \\
\text { a. Develop/test questionnaires and protocols; } \\
\text { conduct interviews } \\
\text { b. Collect useful information quickly (per advice from text, } \\
\text { faculty and client) }\end{array}$ & $\begin{array}{l}\text { - Knowledge management (KM) documents } \\
\text { - Share/discuss with entire team } \\
\text { t. "Pre-wire” instructors } \\
\text { - Get timely "reaction” from client (go/no go) }\end{array}$ \\
\hline $\begin{array}{l}\text { 5. Interpret the Results } \\
\text { a. Find the "so what" insight assess the risks } \\
\text { b. Draw conclusions } \\
\text { c. Generate solutions (per client capabilities) } \\
\text { d. Forecast impact of change }\end{array}$ & $\begin{array}{l}\text { - Gap analysis } \\
\text { - Financial analysis } \\
\text { - Analysis and forecasts using proven models and tools } \\
\text { - } \quad \text { Recortunity matrix — short and long term } \\
\quad \text { primary client stakeholders }\end{array}$ \\
\hline $\begin{array}{l}\text { 6. Present Your Ideas } \\
\text { a. Develop team strategy for convincing clients that change } \\
\text { is merited and achievable } \\
\text { b. Prepare deliverables to specifications }\end{array}$ & $\begin{array}{l}\text { - Written strategic plan that outlines a significant change management } \\
\text { recommendation, including implementation guidelines, timetable and } \\
\text { budget } \\
\text { - PowerPoint slides for final presentation }\end{array}$ \\
\hline
\end{tabular}

had a very successful history of working together on various productivity projects with the ISM program. The connection between Company A and WMU has led to the project successes in Table 5.

WMU students have made several key contributions to Company A's bottom line. According to their project manager, the work performed by the students has reduced inventory costs, increased visibility of products, widened margins, and improved return on investment. WMU students have also provided extremely valuable suggestions for Company A's indirect purchasing department. The solutions posed by students reduced costs and provided the organization with an excellent purchasing strategy to reduce its supply base. In working together on these productivity projects, WMU students and Company A have both benefited immensely.

\subsection{Company B}

The MGMT 3810 class serves all sized companies in several industries. Company B is a smaller 100-person manufacturing facility and distributes doors to fit the needs of a wide customer base which consists of members from various industries such as restaurants, hospitals, and construction sites.

On one process improvement project, students recommended set up times could be reduced by $50 \%$. By having a removable tool, the team eliminated repetitive steps and proved the proposal's value with a cost analysis presentation to upper management. In a separate project for Company B, students reduced downtime and created standardization by developing current best practices for several manufacturing processes. Within these formal, written guidelines, the students documented all steps, parts, and 'tribal knowledge' needed to create a quality management system. In doing so, the students reduced cycle times, eliminated waste within the current practices, and improved Company B's ability to cross-train employees.

In both projects, students applied the A3 problem-solving approach to determine the root cause of the issues. Knowledge-based decision making allowed the students to propose and implement positive change for Company B [25] [26]. 


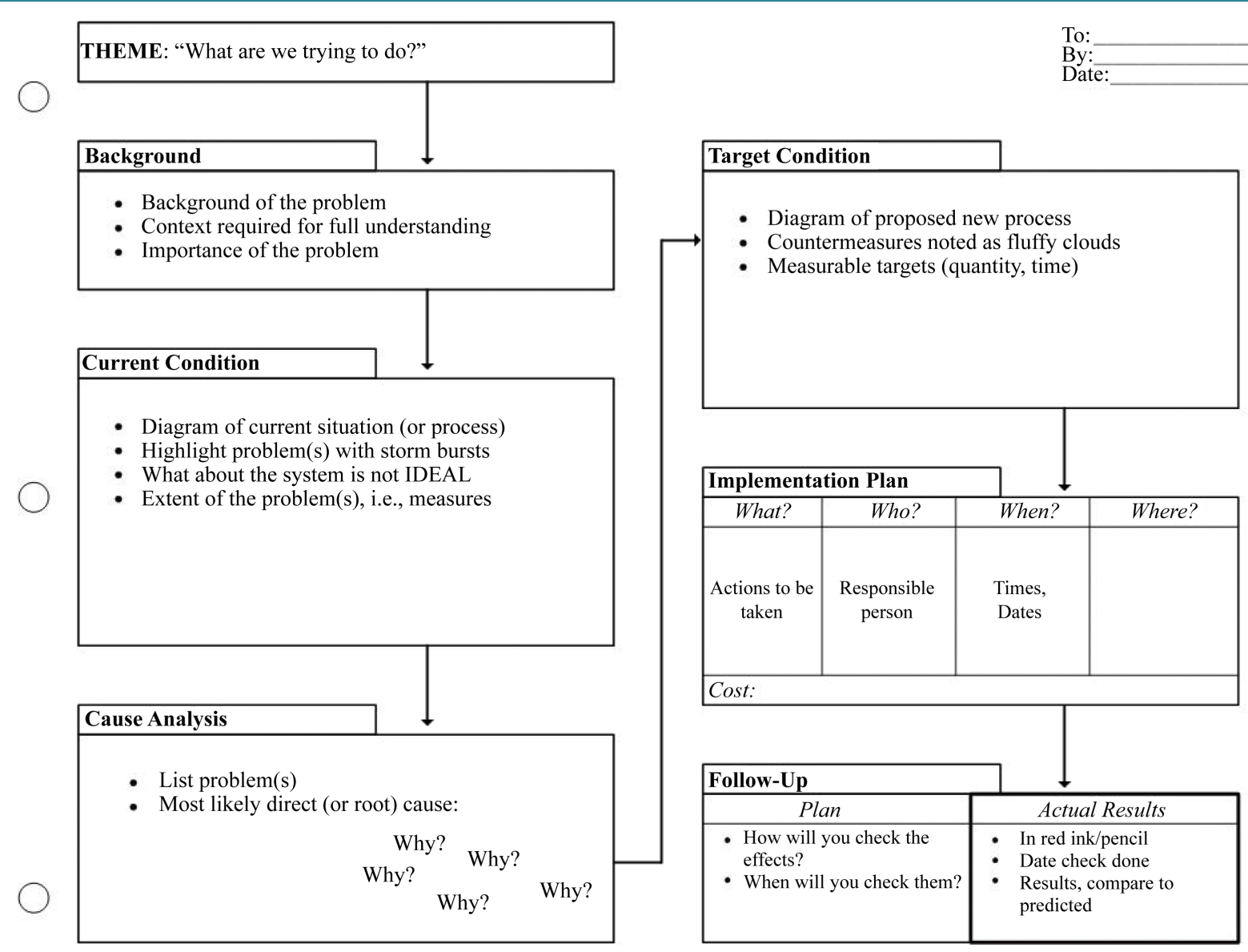

Figure 2. A3 analysis format.

Table 5. Company A projects.

\begin{tabular}{ll}
\hline Project & Description \\
\hline Applying Lean Manufacturing Practices & $\begin{array}{l}\text { Part consolidation to improve Company A's use of production floor space. The students collected } \\
\text { data on parts by weight, location, and container and then proposed solutions to reduce inventory } \\
\text { and implement a JIT system for the production floor. }\end{array}$ \\
The Supermarket Project & $\begin{array}{l}\text { ISM students were assigned to Company A's warehouse for a major product division. The } \\
\text { students took inventory of parts used, size and weight, standardized shipment packaging } \\
\text { and holding bins, and implemented improvements for circulation of parts }\end{array}$ \\
Indirect Supply Consolidation & $\begin{array}{l}\text { The group formulated short- and long-term goals that included creating procedures for proper } \\
\text { oversight of the indirect supply base, setting buyer authorization levels, creating a scorecard to } \\
\text { evaluate indirect suppliers, suggesting up-to-date ERP systems and e-tools, creating a preferred } \\
\text { list, using strategic purchasing methods. } \\
\text { Kanban Project }\end{array}$ \\
$\begin{array}{l}\text { Company A's product line team leaders worked with a group of ISM students to effectively } \\
\text { change the Kanban sizes and reorder quantities of all the parts on an integral product line. }\end{array}$
\end{tabular}

\section{Conclusions}

Western Michigan University's ISM program is continuously producing top talent for its target job market. Employers that consistently acquire students from WMU are appreciating the results. A manager from a Fortune 100 company in Ohio regularly speaks to WMU graduates' abilities to quickly adapt to the challenges of their new job - they are job-ready day one. Receiving such high praise from a recruiter at a prominent global organization is a great indicator that WMU has successful teaching methods in place within a comprehensive curricu- 
lum; and it also reveals the value of WMU's collaboration with local companies to give its student a unique advantage in the business world.

In 2016, the program ranked fifth for undergraduate education on a listing of the top 100 universities for supply chain education, produced by SCM World, a cross-industry learning community powered by the world's most influential supply chain practitioners. The program received a No. 7 overall ranking. Notably, the curriculum ranked No. 2 in the industrial sector. According to survey administrators, "Having secured a top five ranking for its undergraduate supply chain program, Western Michigan demonstrates a solid commitment to crossfunctional education. Especially among industrials, this program scores well”. Additionally, the program was ranked No. 5 for its preparation of professionals in management and No. 2 in purchasing and procurement. The survey respondents were able to select from among 190 university and college options on the poll and were given the option to specify other universities or business schools not available in the pre-populated list. Respondents were supply chain professionals in a variety of industries.

As of now, there are six competencies that universities often focus on, in order to better meet the needs of today's competitive and global job market [25] [26]:

1. Collaboration with employers.

2. Teamwork skills of graduates.

3. New developments in technology.

4. Hands-on experience.

5. Critical thinking.

6. Oral/written communication.

WMU's ISM program and its live experiential lean problem-solving class are setting graduates up for success by challenging them in all of the above areas. Students gain hands-on experience by working within a team and using a proven structured approach to problem solving (A3), all in the process of solving real supply chain problems. As a result, its graduates are able to adapt quickly in their new positions and they are seeing a tangible increase in job benefits and the number of potential employers. Western Michigan University's Integrated Supply Management program is successfully closing the gap between graduates' abilities and employer expectations though continuous collaboration with industry.

\section{References}

[1] U.S. Department of Education, National Center for Education Statistics, Integrated Postsecondary Education Data System (IPEDS) (2012) Fall Enrollment Survey (IPEDS-EF:96-99). IPEDS Spring 2001 through Spring 2011, Enrollment Component; and Enrollment in Degree-Granting Institutions Model, 1980-2010. https://nces.ed.gov/programs/projections/projections2021/sec5c.asp

[2] Labor Force Statistics from the Current Population Survey (2015) Bureau of Labor Statistics. http://www.bls.gov/home.htm

[3] Pohlen, T.L. (2011) Meeting the Challenge of Educating the Transportation and Logistics Professional. Transportation Journal, 50, 84-90. http://dx.doi.org/10.5325/transportationj.50.1.0084

[4] Cecere, L. (2012) Supply Chain Talent: The Missing Link? Supply Chain Insights, LLC. http://supplychaininsights.com/supply-chain-talent-the-missing-link

[5] (2015) 17th Annual Global CEO Survey: Fit for the Future, Capitalizing on Global Trends. Price Water House Coopers International, Limited. http://www.pwc.com/gx/en/ceo-survey/2014/index.jhtml

[6] (2014) The University of Tennessee. Global Supply Chain Institute, Bending the Chain, Knoxville.

[7] http://www2.deloitte.com/us/en/pages/operations/articles/supply-chain-talent-of-the-future-survey.html

[8] http://www.mhlroadmap.org/downloads/mhl_roadmap.pdf

[9] http://www.cips.org/supply-management/news/2015/november/third-of-supply-chain-processes-inadequate/

[10] 10 Questions State Legislators Should Ask about Higher Education. Are College Students Prepared to Enter the Workforce? ALEC.org.

https://www.alec.org/app/uploads/2011/09/2011-10-Questions-Legislators-Should-Ask-About-Higher-Education.pdf

[11] Driscoll, E. (2014) What Employers Want from College Grads. Fox Business. http://www.foxbusiness.com/features/2012/06/04/what-are-employers-want-from-college-grads.html

[12] (2006) Are They Really Ready to Work? Employers' Perspectives on the Basic Knowledge and Applied Skills of New Entrants to the 21st Century Workforce, the Conference Board, Corporate Voices for Working Families, Partnership 
for 21st Century Skills, Society for Human Resource Management, 38. http://www.21stcenturyskills.org/documents/FINAL_REPORT_PDF09-29-06.pdf

[13] Hart, P.D. (2006) How Should Colleges Prepare Students to Succeed in Today’s Global Economy? http://www.aacu.org/leap/documents/Re8097abcombined.pdf

[14] Barr, T.F. and McNeilly, K.M. (2002) The Value of Students' Classroom Experience from the Eyes of the Recruiter: Information, Implications, and Recommendations for Marketing Recruiters. Journal of Marketing Education, 24, 168173.

[15] Barrows, H.S. and Tamblyn, R.M. (1980) Problem-Based Learning: An Approach to Medical Education. Springer, New York.

[16] Bell, S. (2010) Project-Based Learning for the 21st Century: Skills for the Future. The Clearing House, 83, 39-43. http://dx.doi.org/10.1080/00098650903505415

[17] DeFillippi, R. and Milter, R. (2009) Problem-Based and Project-Based Learning. In: Armstrong, S.J. and Fukami, C.V., Eds., Sage Handbook of Management Learning, Education and Development, Sage Publications Ltd., London, 344-363. http://dx.doi.org/10.4135/9780857021038.n18

[18] Dallimore, E.J. and Souze, T.S. (2002) Consulting Course Design: Theoretical Frameworks and Pedagogical Strategies. Business Communication Quarterly, 65, 86-113. http://dx.doi.org/10.1177/108056990206500408

[19] Heriot, K.C., Cook, R., Jones, R.C. and Simpson, L. (2008) The Use of Student Consulting Projects as an Active Learning Pedagogy: A Case Study in a Production/Operations Management Course. Decision Sciences Journal of Innovative Education, 6, 463-481. http://dx.doi.org/10.1111/j.1540-4609.2008.00186.x

[20] Hmelo-Silver, C.E. (2004) Problem-Based Learning: What and How Do Students Learn? Educational Psychology Review, 16, 235-266. http://dx.doi.org/10.1023/B:EDPR.0000034022.16470.f3

[21] Kanet, J. and Barut, M. (2003) Problem-Based Learning for Production and Operations Management. Decision Sciences Journal of Innovative Education, 1, 99-118. http://dx.doi.org/10.1111/1540-5915.00007

[22] Lehmann, M., Christensen, P., Du, X. and Thrane, M. (2008) Problem-Oriented and Project-Based Learning (POPBL) as an Innovative Learning Strategy for Sustainable Development in Engineering Education. European Journal of Engineering Education, 33, 283-295. http://dx.doi.org/10.1080/03043790802088566

[23] Savery, J. (2006) Overview of Problem-Based Learning: Definitions and Distinctions. Interdisciplinary Journal of Problem-Based Learning, 1, 9-20. http://dx.doi.org/10.7771/1541-5015.1002

[24] Senge, P., Lichtenstein, B., Kaeufer, K., Bradbufy, H. and Carroll, J. (2007) Collaborating for Systemic Change. Sloan Management Review, 48, 44-53.

[25] Sroufe, R. and Ramos, D. (2011) MBA Program Trends and Best Practices in Teaching Sustainability: Live Project Courses. Decision Sciences Journal of Innovative Education, 9, 349-369. http://dx.doi.org/10.1111/j.1540-4609.2011.00315.x

[26] Ramos, D.P. and Sroufe, R. (2015) Leveraging Collaborative, Thematic Problem-Based Learning to Integrate Curricula. Decision Sciences Journal of Innovative Education, 13, 151-176. http://dx.doi.org/10.1111/dsji.12063

[27] Rubrich, L. (2010) A3 Problem Solving: What It Is ... and What It Isn't. http://www.reliableplant.com/Read/22984/a3-problem-solving-lean 